\title{
WALI NIKAH BAGI JANDA DI BAWAH UMUR DALAM PERSPEKTIF HUKUM ISLAM
}

\author{
Oleh : \\ Muharir, M.E.Sy \\ (Dosen STEBIS IGM Palembang)
}

\begin{abstract}
Imam Maliki, Imam Syafi'i, and Imam Hambali based on the opinion of the four priests of a widow who will remarry must with the consent of his guardian and he should not marry himself. So if the widow is remarried then the presence of a guardian for marriage is a must and marriage without a guardian is not legal. Imam Hanafi, according to the opinion of Hanafi imam, the marriage of a widow without legal guardian is legitimate but the guardian may prohibit the marriage if the marriage is deemed incompatible with religious shari'ah. Guardian marriage widow must exist in marriage even though he has no right to force or prevent widowed marriage the. If the marriage guardian of the widow disagrees and has no clear reason for his rejection then his marriage guardian may be replaced by a judge. The marriage guardian of a widow must also the conditions of the marriage guardian and according to the order of marriage guardian in Islamic.
\end{abstract}

\section{A. PENDAHULUAN}

Madzhab Hanafiyah berpandangan bahwa status wali hanyalah syarat perkawinan bukan rukun perkawinan. Atas hal ini, ulama Hanafiyah meringkas rukun nikah terdiri dari ijab dan qabul. Status wali menjadi syahnya perkawinan khusus anak kecil baik perempuan ataupun laki-laki, orang gila (majnun, perempuan atau laki-laki) meskipun orang dewasa. ${ }^{1}$ Sedangkan orang dewasa yang sudah baligh baik janda ataupun gadis tidak berada dalam kekuasaan wali, tetapi cukuplah bagi kedua mempelai tersebut dengan akad nikah (ijab atau qabul) dengan syarat keduanya kafaah, dan jika tidak begitu maka wali memiliki hak untuk membatalkan atau memfasakh akad tersebut.

Dengan demikian, dapat dipahami bahwa status wali dalam madzhab Hanafiyah, bukan merupakan rukun sebagai syarat sahnya perkawinan dengan syarat tertentu. Argumentasi madzhab Hanafiyah didasarkan kepada bahwa aqad nikah sama dengan aqad jual beli. Oleh

${ }^{1}$ Abdul Hamid Mahmud, Al Fiqhu Al Hanafi Fii Tsaubi Al Jadid, Jus II, (Damaskus: Dar Al Qalam, 2000), h. 63. 
karena itu, syaratnya cukup dengan ijab dan qabul. Posisi wali hanya diperuntukkan bagi pasangan suami isteri yang masih kecil. Selain itu, secara istidlal, Hanafiyah berpandangan bahwa al-Quran ataupun hadits yang dijadikan hujjah terhadap status wali sebagai rukun nikah, tidak memberikan isyarat bahwa wali tersebut sebagai rukun nikah. ${ }^{2}$

Oleh karena itu, dalam madzhab Hanafiyah, posisi wali itu tidak mutlak dan kalaupun ada, hanya diperuntukkan kepada wanita yang masih gadis (belum dewasa). Bahkan dalam tulisan Abu Zahroh yang dikutip Jawad Mughniyah, menjelaskan bahwa madzhab Hanafiyah mengatakan bahwa wanita yang telah baligh dan berakal sehat boleh memilih sendiri suaminya dan boleh pula melakukan akad nikah sendiri, baik dia perawan maupun janda. Tidak ada seorang pun yang mempunyai wewenang atas dirinya atau menentang pilihannya, dengan syarat, orang yang dipilihnya itu se-kufu (sepadan) dengannya dan maharnya tidak kurang dari mahar mitsil tetapi bila dia memilih seorang laki-laki yang tidak se- kufu dengannya, maka walinya boleh menentangnya, dan meminta kepada qadhi untuk membatalkan akad nikahnya. Kalau wanita tersebut kawin dengan laki-laki lain dengan mahar kurang dari mahar mitsil, qadhi boleh diminta membatalkan akadnya bila mahar mitsil tersebut tidak dipenuhi oleh suaminya. ${ }^{3}$

Imam malik sebagai imam dalam madzhab Malikiyah sebagaimana dikutip Wahbah Zuhalli berpendapat bahwa tidak terjadi perkawinan kecuali dengan wali. Wali adalah syarat sahnya pernikahan. Atas pemikiran imam Malik ini, maka selanjutnya para pengikut imam Malik atau dikenal dengan Malikiyah, lebih tegas berpendapat bahwa wali adalah rukun dari sebagian rukun nikah, tidak terjadi akad nikah tanpa adanya wali. ${ }^{4}$

Madzhab Syafieiyah menetapkan bahwa wali adalah salah satu rukun nikah, tidak sah pernikahan kecuali dengan wali. Sebagaimana keberadaan saksi, wali harus ada dalam suatu pernikahan. Nikah tidak sah tanpa wali laki-laki, mukallaf, merdeka, muslim, adil, dan berakal sempurna. Namun, pernikahan kafir dzimmi tidak butuh keislaman wali, dan orang Islam tidak bisa menjadi wali baginya, kecuali pemerintah. Pemerintah boleh menikahkan wanita-wanita kafir dzimmi, jika tidak mempunyai wali nasab. Sesuai dengan ketentuan kewalian yang berlaku. Seorang wanita tidak boleh menikahkan dirinya sendiri, meski dengan izin walinya. Dia juga tidak boleh menikahkan orang lain, meski ditunjuk

\footnotetext{
${ }^{2}$ Dedi Supriyadi, Mustofa, Perbadingan Hukum Perkawinan Di Dunia Islam (Bandung: Pustaka Al Fikriis, 2009), h.3

${ }^{3}$ Muhammad Jawad Mughniyah, Fiqh Lima Mazhab ( Jakarta: Lentera, 2001), h.348

${ }^{4}$ Wahbah Zuhalli, Al Fiqh Al Malik Al Muyassar, Juz III,.Op.cit, h.96. 36

Al-Qodhi : Jurnal Hukum Keluarga Islam

Vol. I, No. I (لuli 2019)
} 


\section{Al-Dadhi : Jurnal Hukum Keluarga Islam}

sebagai wakil atau diberi kuasa oleh wali wanita tersebut. Dia juga tidak boleh menerima atau membaca qabul atas pernyataan ijab seseorang. ${ }^{5}$

Mazhab Hanabilah dalam memandang wali, pada dasarnya sama dengan mazhab Malikiyah dan Syafie'iyah. Bahwa ketiga mazhab tersebut berpendapat bahwa" wali itu sangat penting dalam pernikahan. Tanpa wali atau orang yang menggantikan wali, maka nikahnya tidak sah. Seorang wanita tidak boleh menikah sendiri dengan akad pernikahannya sendiri dalam keadaan apapun baik kepada gadis atau lelaki yang dewasa atau yang belum dewasa, kecuali janda yang harus diminta ijin dan ridlonya.

Pernyataan Imam al-Syafi'i ini bahwa janda belum dewasa tidak boleh dipaksa menikah oleh wali nikah. Masalah yang muncul yaitu apa yang melatarbelakangi Imam al-Syafi'i tidak mengharuskan adanya persetujuan wali nikah dalam akad nikah bagi janda belum dewasa. Hal ini tentunya harus diteliti kondisi sosial politik dan sosio historis yang mengitari kehidupan Imam al-Syafi'i. Kondisi ini berimplikasi pada penggunaan istinbat hukum dalam konteks kedudukan wali nikah bagi janda di bawah umur. Janda yang belum dewasa dianggap masih belum dapat menentukan dan memutuskan calon suami yang baik.

Dalam kehidupan sehari-hari masih ada berbagai macam permasalahan yang timbul terutama dalam masalah pernikahan. Melihat realitas yang terjadi saat ini serta pergaulan muda mudi masa kini banyak ditemukan terjadinya kasus-kasus perzinahan yang berujung kepada terjadinya pernikahan dimana mempelai wanitanya dalam kondisi hamil dan nada yang ditinggalkan oleh suaminya sehingga wanita tersebut menjadi janda dan ingin menikah lagi dengan laki-laki lain. Hal ini dianggap sepele oleh sebagian kalangan yang notabenenya kurang memahami masalah agama sehingga tidak mempersoalkan lagi masalah tersebut serta menganggap hal tersebut merupakan hal yang benar dan biasa terjadi dikalangan mereka. Padahal kalau dikembalikan kepada masalah agama terutama dalam masalah pernikahan maka syarat sahnya suatu pernikahan adalah harus adanya wali. Jika terjadi dalam suatu pernikahan walinya tidak sah maka akan berpengaruh kepada sah tidaknya suatu pernikahan dan implikasinya ketika suatu pernikahan tidak sah maka hubungan yang dijalani tersebut pun akan menjadi suatu

${ }^{5}$ Syaikh Mahmoud Syaltout, Syaikh M. Ali As Sayis, Perbandingan Mazhab Dalam Masalah Fiqih (Jakarta: Bulan Bintang, 1973), h.114.

${ }^{6}$ Abu Muhammad Abdullah bin Ahmad bin Muhammad bin Qudamah Al Maqdisi Al Damasqi, Al Mughni (Riyad: Dar „Alim al Kutb, 2009), h.345. 


\section{Al-Dadhi : Jurnal Hukum Keluarga Islam}

hubungan perzinahan dan hal ini akan terjadi terus sampai generasi seterusnya.

Di desa Simbar Waringin, Kecamatan Trimurjo petugas PPN menemukan beberapa kasus di daerah tersebut pasangan yang menikah pihak wanitanya dalam keadaan janda di bawah umur sudah mempunyai seorang anak perempuan yang masih berusia satu tahun dan dipaksa menikah oleh bapak kandungnya dan yang menjadi wali nikahnya adalah bapaknya. ${ }^{7}$ Di Kecamatan yang sama di desa Adipuro ada seorang janda di bawah umur yang usianya masih 15 tahun dan melakukan pernikahan dengan seorang laki-laki yang sudah dewasa akan tetapi bapak dari janda di bawah umur tersebut tidak mengizinkan untuk menikah dengan laki-laki tersebut akan tetapi perempuan janda di bawah umur tersebut tetap melangsungkan pernikahan dengan wali nikahnya seorang tokoh agama yang ada di desa tersebut. Kronologis kejadian di tahun 2014, kedua orangtuanya pada waktu itu sedang menunaikan rukun Islam yang ke lima yaitu ibadah haji dan anak perempuan tinggal di rumah sendiri yang masih berusia 15 tahun, setelah kedua orangtua nya pulang dari ibadah haji mendengar cerita bahwa anaknya sedang hamil yang dihamili oleh seorang laki-laki tetangga rumah nya sendiri dan dilangsungkan pernikahan atas persetujuan kedua orangnya, setelah beberapa bulan berjalan anak perempuan tersebut melahirkan anak seorang anak perempuan dan akhirnya anak yang dilahirkan tersebut meninggal dunia disaat berusia lima bulan, pada tahun 2016 anak perempuan janda tersebut ingin menikah dengan seorang laki-laki yang disukainya akan tetapi kedua orang tuanya tidak merestuinya dan akhirnya perempuan janda tersebut tetap melangsungkan pernikahan dengan wali nikahnya tokoh agama setempat dan sampai sekarang masih menjalani hidup berumah tangga. 8

\section{B. KEDUDUKAN WALI NIKAH BAGI JANDA DI BAWAH UMUR DALAM PELAKSANAKAN NIKAH DI KUA KECAMATAN TRIMURJO LAMPUNG TENGAH}

Janda yang kita kenal dalam sebutan masyarakat tentunya sedikit berbeda dengan pengertian janda dalam islam. Seorang wanita yang sudah menjadi janda berhak menikah kembali dan memiliki suami dan hal ini tidak boleh dihalalngi meskipun oleh walinya sendiri.Untuk lebih mengetahui hukum pernikahan janda serta wali nikah bagi janda di bawah umur di wilayah KUA Kecamatan Trimurjo Lampung Tengah.

7 Wawancara dengan Bapak Usman Selaku PPN KUA Trimurjo Lampung Tengah ,Selasa, 15 Januari 2018, pukul. 14.00 WIB

${ }^{8}$ Hasil Wawancara dengan Bapak Usman selaku PPN di KUA Trimurjo Lampung Tengah Selasa, 15 Januari 2018, pukul 14.00 WIB 


\section{Al-Dadhi : Jurnal Hukum Keluarga Islam}

Kasus ini jarang terjadi, tetapi ketika penulis melakukan penelitian di Kampung Simbar Waringin, Kecamatan Trimurjo menemukan pasangan yang menikah wanita berstatus janda di bawah umur berusia lima belas tahun mempunyai seorang anak perempuan yang masih berusia satu tahun dan dipaksa menikah oleh ayah kandungnya, yang menjadi wali nikahnya adalah ayahnya sendiri. Kemudian di desa Adipuro ada seorang janda di bawah umur usianya masih lima belas tahun menikah dengan seorang laki-laki yang sudah dewasa tetapi ayahnyatidak memberi izin, namun demikian pernikahan tersebut tetap dilangsungkan dengan wali nikahnya seorang tokoh agama setempat. Kronologis kejadian di tahun 2014, kedua orangtua si janda sedang menunaikan rukun Islam yang ke lima yaitu ibadah haji, anak perempuan tinggal di rumah sendiri masih berusia 15 tahun, pulang dari ibadah haji mendengar anaknya sedang hamil maka di nikahkan dengan laki-laki yang menghamilinya dengan persetujuan orangtunya, setelah beberapa bulan berjalan lahirlah seorang anak perempuan dan terjadi perceraian, perkawinan hanya berlangsung beberapa bulan dan menyandang status janda di bawah umur tahun 2016, janda tersebut ingin menikah dengan laki-laki yang disukainya tetapi kedua orang tuanya tidak merestui, walaupun demikian tetap melangsungkan pernikahan wali nikahnya tokoh agama setempat dan sampai sekarang masih menjalani hidup berumah tangga. ${ }^{9}$

Kedua kasus di atas menunjukkan eksistensi wali nikah kasus yang pertama di wilayah KUA Trimurjo, seorang janda di bawah umur dipaksa menikah oleh ayahnya, dipaksa disini dalam arti bahwa ayah mempunyai hak penuh dalam memilih pasangan bagi anak perempuan masih di bawah umur tetapi sudah menjadi janda tanpa harus meminta persetujuan terlebih dahulu. Hal ini kalau ditinjau kedudukan Wali Nikah Bagi Janda di Bawah Umur dalam Pelaksanakan Nikah di wilayah KUA Kecamatan Trimurjo Lampung Tengah, ada beberapa pendapat:

Tidak ada upaya untuk menguatkan nikah orang tua ketika penunjukan wali nikah, sehingga banyak terjadi di masyarakat tokoh agama menjadi wali nikah bagi anak janda di bawah umur, sehingga ketika akan melangsungkan akad nikah pihak KUA Kecamatan Trimurjo tidak pernah mengadakan verifikasi data tanggal nikah orang tua dengan tanggal lahir anak. Ketika masyarakat mengetahui janda di bawah umur dan tokoh agama menjadi wali nikah, masyarakat membiarkan hal tersebut, karena mereka beranggapan bahwa tokoh agama boleh menjadi wali nikahnya. Petugas PPN di KUA Trimurjo tidak pernah melakukan manipulasi data untuk persyaratan dalam pernikahan.

9 Hasil Wawancara dengan Bapak Usman selaku PPN di KUA Trimurjo Lampung Tengah Selasa, 15 Januari 2018, pukul 14.00 WIB 


\section{Al-Dadhi : Jurnal Hukum Keluarga Islam}

Ketika ada perempuan janda di bawah umur dan akan melangsungkan pernikahan dan untuk mengetahui anak tersebut adalah perempuan janda di bawah umur seharusnya ada pengakuan dari pihak keluarga atau yang bersangkutan, sehingga bisa diketahui bahwa anak tersebut anak janda atau bukan. sepengetahuan Tokoh Agama di desa Simbarwaringin pernah ada perempuan janda di bawah umur yang di nikahkan atau diwalikan oleh tokoh agama setempat, akan tetapi sudah dinikahkan ulang oleh pihak PPN atau Penghulu setempat, Ketika ada perempuan janda di bawah umur kemudian melangsungkan pernikahan dan yang menjadi wali nikahnhya adalah tokoh agama setempat, dan masyarakat mengetahuinya maka itu suatu aib bagi keluarga tersebut dan akan menanggung malu. Begitu pula jika ada masyarakat mengetahui ada anak perempuan janda di bawah umur dan melangsungkan pernikahan masyarakat tersebut hanya berdiam saja, yang seharusnya yang menikahkan adalah wali hakim ${ }^{10}$. Pendapat Imam Abu Hanifah. Di kalangan ulama terdapat perbedaan pendapat di dalam harus atau tidak adanya wali dalam nikah, Imam Abu Hanifah berpendapat bahwa perempuan boleh menikahkan dirinya sendiri dan boleh pula mewakilkan kepada orang lain untuk menikahkan dirinya jika ia telah boleh menggunakan hartanya. Juga, tidak boleh ia dihalang-halangi kecuali jika menikah dengan orang yang tidak sekufu dengannya. ${ }^{11}$ Imam Hanafi mengatakan bahwa wanita yang telah baligh dan berakal sehat boleh memilih sendiri suaminya dan boleh menikahkan dirinya sendiri,baik dia perawan atau janda. Tidak seorang pun yang mempunyai wewenag atas dirinya atau menentang pilihannya, syarat, orang yang dipilih itu sekufu (sepadan). Tetapi bila ia memilih seorang laki-laki yang tidak sekufu dengannya, maka walinya boleh menentangnya, dan meminta kepada qadhi untuk membatalkan akadnya. Denganalasan untuk menjaga aib yang kemungkinan timbul dari pihak suaminya selama belum hamil atau melahirkan. Jika ternyata sudah hamil atau melahirkan, maka gugurlah haknya untuk meminta pembatalan pengadilan, demi menjaga kepentingan anak dan memilihara kandungannya.Dengan demikian, dapat dipahami bahwa status wali nikah dalam Mazhab Hanafi, bukan merupakan rukun sebagai syarat sahnya pernikahan, melainkan sebagai jalan alternatif atau pelengkap sahnya perkawinan dengan syarat tertentu.

Dari uraian diatas dapat penulis simpulkan bahwa wali nikah menurut mazhab hanafi bahwa wali bukan merupakan syarat sahnya pernikahan dan menurut mazhab hanafi juga wali itu tidak diperlukan,

10 Wawancara dengan Bapak Nasihin Selaku Tokoh Agama Desa Simbarwaringin Lampung Tengah, Senin 30 Maret 2018, pukul. 15.00 WIB

${ }^{11}$ Syaikh al-Allamah Muhammad, Fiqih Empat Mazhab, (Bandung: Hasyimi, 2015), h.

40

Al-Codhi : Jurnal Hukum Keluarga Islam

Vol. I, No. I (لuli 2019) 
tetapi hanya menjadi pelengkap dalam prosesi pernikahan. Akan tetapi jika yang ingin melangsungkan pernikahan adalah anak yang masih kecil atau anak dibawah umur maka anak itu harus mendapat izin dari wali terlebih dahulu, dan menurut mazhab hanafi wali bagi anak yang akan melangsungkan pernikahan bisa menggunakan wali dari pihak ibunya.

Pengakuan terhadap anak perempuan janda di bawah umur, dapat dilakukan dengan:Pengakuan sukarela yaitu: suatu pengakuan yang dilakukan oleh seseorang dengan cara yang ditentukan undang-undang, bahwa ia adalah bapaknya (ibunya) seorang anak yang telah menjadi janda di bawah umur. Dengan adanya pengakuan, maka timbulah hubungan Perdata antara anak dan bapak (ibu) yang telah mengakuinya sebagaimana diatur dalam Pasal 280 KUHPerdata. Pengakuan sukarela dapat dilakukan dengan cara-cara yang ditentukan dalam Pasal 281 KUHPerdata, yaitu :

1. Dalam akta kelahiran si anak Menurut Pasal 281 ayat (1) KUHPerdata, untuk dapat mengakui seorang anak perempuan janda di bawah umur bapak atau ibunya dan atau kuasanya berdasarkan kuasa otentik harus menghadap di hadapan pegawai catatan sipil untuk melakukan pengakuan terhadap perempuan janda di bawah umur tersebut.

2. Pengakuan terhadap anak perempuan janda di bawah umur dapat pula dilakukan pada saat perkawinan orang tuanya berlangsung yang dimuat dalam akta perkawinan sebagaimana diatur dalam Pasal 281 ayat (2). Jo Pasal 272 KUHPerdata.

3. Pengakuan terhadap anak perempuan janda di bawah umur dapat dilakukan dalam akta oteintik seperti akta notaris sebagaimana diatur dalam Pasal 281 ayat (1) KUHPerdata.

4. Dengan akta yang dibuat oleh pegawai catatan sipil, yang dibutuhkan dalam register kelahiran catatan sipil menurut hari Penanggalannya sebagaimana diatur dalam Pasal 281 ayat (2) KUHPerdata.

Dari kedua kasus tentang pernikahan janda di bawah umur yang wali nikahnya oleh bapak kandungnya sendiri ataupun tokoh agagama setempat yang terjadi di Desa Simbarwaringin dan Adipuro Kecamatan Trimurjo Lampung Tengah, maka dampak yang ditimbulkan adalah:

Dampak yang ditimbulkan ketika perempuan janda di bawah umur sedang melangsungkan pernikahan dan tanpa wali nikah Pendapat Imam al-Syafi'i sangat relevan dengan realitas kehidupan masa kini. Jika dibolehkan nikah tanpa wali, maka sebelum nikah orangakan berani mengadakan hubungan badan sebelum nikah karena orang itu akan beranggapan nikah itu sangat mudah, dan jika ia sudah menikah hak dan kewajiban masing-masing menjadi tidak jelas. Kedudukan hukum wanita menjadi lemah apalagi dalam soal waris mewarisi 


\section{Al-Dadhi : Jurnal Hukum Keluarga Islam}

antara bapak dengan anak- anaknya.Problem madaratnya sudah bisa dibayangkan. Karenanya untuk mencegah madaratnya, maka adanya wali sangat diperlukan

Pada dasarnya empat mazhab fiqih memiliki pedoman yang sama dalam menentukan suatu hukum yaitu al-qur'an dan hadits, tetapi empat mazhab fiqih itu berbeda dalam hal menafsirkan al-qur'an dan mentakhrij hadits, sehingga ada perbedaan dalam menentukan hukum tentang wali nikah janda di bawah umur.

Pendapat Imam al-Syafi'i yang mengharuskan adanya wali dalampernikahan sangat relevan dengan realitas kehidupan masa kini. Jikadibolehkan nikah tanpa wali, maka sebelum nikah orang akan beranimengadakan hubungan badan sebelum nikah karena orang itu akanberanggapan nikah itu sangat mudah, dan jika ia sudah menikah hak dankewajiban masing-masing menjadi tidak jelas. Kedudukan hukum wanitamenjadi lemah apalagi dalam soal waris mewarisi antara bapak dengananak-anaknya. Problem madaratnya sudah bisa dibayangkan. Karenanyauntuk mencegah madaratnya, maka adanya wali sangat diperlukan.

Kontekstualisasi pendapat Imam al-Syafi'i tentang keharusan adanya walidalam pernikahan dalam hukum perkawinan kontemporer. Sangat tepatkalau peristiwa pernikahan itu memerlukan wali dan melibatkan keluarga,terutama wali. Berbeda dengan masyarakat Barat yang sudah "modern",peristiwa pernikahan relatif hanya melibatkan mereka yang menikah saja.Jadi, lebih bersifat individual. Dalam masyarakat adat atau masyarakatyang bersifat kekeluargaan atau masyarakat yang hubungankekeluargaannya masih kuat, keberadaan wali masih sangat dibutuhkan. Menafikan keluarga dalam masalah pernikahan bukan saja bertentangan,tetapi juga akan terasa janggal dan tidak lazim dilakukan.Dalam hubungannya dengan wali nikah bagi janda di bawah umur, Imamal-Syafi'i menggunakan metode istinbat hukum berupa hadis bersumberdari Abu Musa dari Nabi SAW beliau bersabda : tidak ada nikah samasekali kecuali dengan adanya seorang wali (HR Kelompok Imam limakecuali an-Nasa'i). Wali nikah menurut mazhab hanafi bahwa wali bukan merupakan syarat sahnya pernikahan dan menurut mazhab hanafi juga wali itu tidak diperlukan, tetapi hanya menjadi pelengkap dalam prosesi pernikahan. Akan tetapi jika yang ingin melangsungkan pernikahan adalah anak yang masih kecil atau anak dibawah umur maka anak itu harus mendapat izin dari wali terlebih dahulu, dan menurut mazhab hanafi wali bagi anak yang akan melangsungkan pernikahan bisa menggunakan wali dari pihak ibunya.

Menurut imam Hambali, kehadiran wali merupakan salah satu rukun nikah artinya disini bahwa bagi seorang perempuan tidak sah 


\section{Al-Dadhi : Jurnal Hukum Keluarga Islam}

menikah tanpa adanya wali. Yang menjadi dasar penetapan keharusan adanya wali adalah Qur'an dan hadis. Sedangkan Mazhab Hanafi status wali bukan merupakan rukun pernikahan, maka ketika anak tersebut akan melangsungkan pernikahan dalam masalah wali tidak ada masalah, karena pernikahannya tidak menggunakan wali tetapi hanya ijab dan qabul saja. Semua kerabat dari ibunya baik kerabat dekat maupun jauh dibenarkan untuk menjadi wali nikah dalam Mazhab Hanafi wali hanya diperuntukkan bagi wanita yang belum dewasa.Dan wanita yang baligh dan berakal sehat boleh menikahkan dirinya sendiri atau menikah tanpa dengan wali dengan syarat laki-laki yang menikah dengannya adalah lakilaki yang sekufu.

\section{TINJAUAN HUKUM ISLAM TERHADAP KEDUDUKAN WALI NIKAH BAGI JANDA DI BAWAH UMUR DI KECAMATAN TRIMURJO LAMPUNG TENGAH.}

Menurut TM.Hasbi Ash Siddieqy, bahwa jumhur ulama berpendapat, salah satu ciri orang dianggap telah baligh, adalah bila dia sudah bermimpi. Seseorang baru bisa dibebani hukum, bila sudah berusia dewasa.Apabila seorang anak lelaki telah berusia limabelas tahun, atau telah tumbuh kumis dan bulu kemaluan, dipandang telah dewasa. Menurut Imam Abu Hanifah anak lelaki dianggap baligh pada saat dia berusia 18 tahun, sedangkan anak perempuan pada saat dia memasuki 17 tahun. ${ }^{12}$

Pasal 7 Undang-undang Nomor 1 Tahun 1974 ayat (1) menyatakan bahwa "perkawinan hanya diizinkan jika pihak pria sudah mencapai umur 19 (sembilan belas) tahun dan pihak wanita sudah mencapai umur 16 (enam belas) tahun". Ketentuan batas umur ini, seperti disebutkan dalam Kompilasi Hukum Islam pasal 15 ayat (1) didasarkan kepada pertimbangan kemaslahatan keluarga dan rumah tangga perkawinan.Ini sejalan dengan prinsip yang diletakkan UU Perkawinan, bahwa calon suami isteri harus telah masak jiwa raganya, agar dapat mewujudkan tujuan perkawinan secara baik tanpa berakhir pada perceraian dan mendapat keturunan yang baik dan sehat. Untuk itu harus dicegah adanya perkawinan antara calon suami isteri yang masih di bawah umur. ${ }^{13}$

Berdasarkan keterangan di atas bahwa menurut penulis, wali dalam perkawinan sangat penting.Pendapat yang lebih besar manfaatnya adalah yang menganggap bahwa wali itu merupakan salah satu rukun

${ }^{12}$ Ibid

${ }_{13}$ Ahmad Rofiq, Hukum Islam Di Indonesia, Jakarta: PT Raja Grafindo Persada, 1997, h. 76-77. 


\section{Al-Dadhi : Jurnal Hukum Keluarga Islam}

nikah. Dengan kata lain pendapat yang lebih maslahat adalah yang menganggap nikahtanpa wali adalah batal. Karena peran dan fungsi wali sangat penting. Pertama, adanya wali adalah untuk menghindari jangan sampai kaum wanita dibohongi atau ditipu laki-laki. Dengan adanya wali, maka dapat diselidiki siapa sebenarnya laki-laki itu.Kedua, dengan adanya wali maka orang tidak akan mempermainkan arti sebuah perkawinan. Tanpa wali, orang akan dengan mudah mengaku telah menikah, sementara ia tidak memiliki bukti yang kuat, hal ini bias mengakibatkan banyaknya kawin dibawah tangan.

\section{PENUTUP}

Simpulan utama adalah wali nikah bagi janda di bawah umur yang akan melangsungkan pernikahannya. Sesuai dengan perspektif hukum Islam, yaitu:

Eksistensi wali nikah di wilayah KUA Trimurjo, seorang janda di bawah umur dipaksa menikah oleh ayahnya, dipaksa disini dalam arti bahwa ayah mempunyai hak penuh dalam memilih pasangan bagi anak perempuan masih di bawah umur tetapi sudah menjadi janda tanpa harus meminta persetujuan terlebih dahulu. Hal ini kalau ditinjau kedudukan Wali Nikah Bagi Janda di bawah umur dalam pelaksanakan nikah di wilayah KUA Kecamatan Trimurjo Lampung Tengah, ada beberapa pendapat:Tidak ada upaya untuk menguatkan nikah orang tua ketika penunjukan wali nikah, sehingga banyak terjadi di masyarakat tokoh agama menjadi wali nikah bagi anak janda di bawah umur, sehingga ketika akan melangsungkan akad nikah pihak KUA Kecamatan Trimurjo tidak pernah mengadakan verifikasi data tanggal nikah orang tua dengan tanggal lahir anak. Ketika masyarakat mengetahui janda di bawah umur dan tokoh agama menjadi wali nikah, masyarakat membiarkan hal tersebut, karena mereka beranggapan bahwa tokoh agama boleh menjadi wali nikahnya. Petugas PPN di KUA Trimurjo tidak pernah melakukan manipulasi data untuk persyaratan dalam pernikahan.

Imam maliki, Imama Syafi'i, dan Imam Hambali bedasarkan pendapat empat imam seorang janda yang akan menikah kembali harus dengan persetujuan walinya dan ia sama sekali tidak boleh menikahkah dirinya sendiri. Sehingga jika janda tersebut menikah lagi maka kehadiran wali untuk menikahkannya merupakan suatu keharusan dan nikah tanpa wali tidaklah sah.Imam Hanafi, menurut pendapat imam Hanafi pernikahan seorang janda tanpa wali hukumnya sah-sah saja namun sang wali boleh melarang pernikahan tersebut apabila dirasa pernikahan tersebut tidak sesuai dengan syariat agama misalnya sang wanita menikah dengan laki-laki yang berbeda agamanya.Apabila janda tersebut 
masih belum mencapai usia baligh atau dewasa maka wali dari janda tersebut tidak boleh menikahkanya. Jika ia dinikahkan meskipun oleh walinya sendiri maka hukum pernikahnnya tidaklah sah atau batal, apabila sang janda atau wanita tersebut telah mencapai usia baligh atau dewasa maka ia boleh dinikahkan kembali oleh walinya namun harus dengan persetujuan wanita atau janda tersebut, pernikahan tersebut terlarang jika janda tersebut adalah muhrim atau berdasarkan pengertian mahram maka ia adalah wanita yang haram dinikahi oleh mempelai pria.Wali nikah janda haruslah ada dalam pernikahan meskipun ia tidak berhak memaksa atau menghalangi pernikahan janda tersebut. Apabila wali nikah dari sang janda tidak setuju dan tidak memiliki alasan yang jelas tentang penolakannya tersebut maka wali nikahnya dapat digantikan oleh seorang wali hakim. Wali nikah seorang janda juga harus memenuhi syarat-syarat wali nikah dan sesuai urutan wali nikah dalam islam. 


\section{Daftar Pustaka}

Abd Ar-Rahman Al-Jaziri , Al-Fiqh Ala Al-Madzahib Al-Arba'ah, Jilid 4 , Berut, Dar Al-Fikr

Abdul Gufron, Analisis pendapat imam al-syafi'i tentang wali Nikah bagi janda di bawah umur, (Skripsi, Untuk meraih Sarjana Hukum Islam), Semarang: Perpustakaan Perpustakaan IAIN Walisongo Semarang, 2010. www//https:Hukum Keluarga Islam,tanggal 20 Januari 2016

Abdul Hamid Mahmud, Al Fiqhu Al Hanafi Fii Tsaubi Al Jadid, Jus II, (Damaskus: Dar Al Qalam, 2000)

Abdul Manan, Aneka Masalah Hukum Perdata Islam di Indonesia, (Jakarta: Kencana, 2018)

Abdul Rahman Ghozali, Fiqh Munakahat, (Jakarta : Prenada Media Group, 2010) cet ke-4 h.169

Abu Daud. Juz II, h.95, lihat juga al-Turmuzi, Juz II, h.280-283, Ahmad bin Hambal, Juz I h.250. Kualitas hadist di atas termasuk hadis sahih, karena periwayatnya tidak ada yang memiliki cacat. Muhammad Jawad Mughniyah. 2008. Fiqih Lima Mazhab. Penerj. Masykur dkk. Jakarta: Lentera.

Abu Muhammad Abdullah bin Ahmad bin Muhammad bin Qudamah Al Maqdisi Al Damasqi, Al Mughni (Riyad: Dar „Alim al Kutb, 2009)

Achmad Kuzari, Nikah Sebagai Perikatan, Jakarta: PT.Raja Grafindo Persada, 1995

Ahmad Rofiq, Hukum Islam Di Indonesia, Jakarta: PT Raja Grafindo Persada, 1997

Al-Imam Abi Abdullah Muhammad bin Idris al-Syafi' '̂, Al-Umm, Juz. 5, (Beirut: Dâr al- Kutub al-Ilmiah, tth)

Al-San'ani, Abdurrahman Al-Kahlani, Subulu Al-Salam, Kitabun Nikah, Jilid III, (Beirut: Dar al-Fikr, tt.)

al-Turmuzi, Jilid 2, h.280-281, Abu Daud, Juz 2 
Al-Dadhi : Jurnal Hukum Keluarga Islam

\section{E-ISSN :}

Amir Syarifuddin, Garis-garis Besar Fiqih ( Jakarta: Kencana, 2003) 